Caring : Jurnal Keperawatan

Vol.8, No. 1, Maret 2019, pp. $32-41$

ISSN 1978-5755 (Online)

DOI: 10.29238

Journal homepage: http://e-journal.poltekkesjogja.ac.id/index.php/caring/

\title{
Hubungan citra tubuh dengan kesejahteraan spiritual pada pasien hemodialisis di RS PKU Muhammadiyah Gamping
}

\section{Corelation body image with being in hemodialysis patient in RS PKU Muhammadiyah Gamping}

\author{
Tendy Ar Riqi ${ }^{1 a^{*}}$, Sutejo ${ }^{2 b}$, Erika Nurwidayanti ${ }^{1}$ \\ ${ }^{1}$ Prodi S1 IImu Keperawatan STIKes Guna Bangsa Yogyakarta \\ 2 Jurusan Keperawatan Poltekkes Kemenkes Yogyakarta \\ a emailtendy@gmail.com \\ b decsuthe@yahoo.com
}

\section{HIGHLIGHTS}

\section{ARTICLE INFO}

\section{Article history}

$-$

Keywords:

Body image

Chronic renal failure

Hemodialysis

Spiritual wellbeing

\section{Kata kunci:}

Citra tubuh

Gagal ginjal kronis

Hemodialisis

Kesejahteraan spiritual

\section{A B S T R A C T / A B S T R A K}

\begin{abstract}
Hemodialysis would affect body image and have the impact on spiritual wellbeing of patients due to variety changes in the patient's body. The purpose of this study was to determine the relationship between body image and spiritual wellbeing of patients undergoing hemodialysis. The research method is descriptive correlative with cross sectional approach. The study was conducted in PKU Muhammadiyah Hospital Gamping with a sample of 60 respondents. The sampling method is purposive sampling. Data collection tool in this study is a questionnaire with 22 statements. Data was analyze by using univariate and bivariate analysis using with chi square tests. The results showed that there is a relationship between body image and spiritual wellbeing of patients with chronic renal failure undergoing hemodialysis with $p$ value $(0,027)<\alpha$ $(0,05)$. This study recommend hemodialysis unit to further improve performance in providing comprehensive care nursing practice both physical and psychosocial in patients with chronic renal failure undergoing hemodialysis especially on the subject of body image disturbance that will affect the spiritual wellbeing of patients.
\end{abstract}

Hemodialisis akan mempengaruhi citra tubuh dan berdampak pada kesejahteraan spiritual pasien karena berbagai perubahan dalam tubuh pasien. Tujuan dari penelitian ini adalah untuk mengetahui hubungan antara citra tubuh dan kesejahteraan spiritual pasien yang menjalani hemodialisis. Metode penelitian ini adalah deskriptif korelatif dengan pendekatan cross sectional. Penelitian dilakukan di Rumah Sakit Gamping PKU Muhammadiyah dengan sampel 60 responden. Metode pengambilan sampel adalah purposive sampling. Alat pengumpulan data dalam penelitian ini adalah kuesioner dengan 22 pernyataan. Data dianalisis dengan menggunakan analisis univariat dan bivariat dengan uji chi square. Hasil penelitian menunjukkan bahwa ada hubungan antara citra tubuh dan kesejahteraan spiritual pasien dengan gagal ginjal kronis yang menjalani hemodialisis dengan nilai $p$ $(0,027)<\alpha(0,05)$. Penelitian ini merekomendasikan unit hemodialisis untuk lebih meningkatkan kinerja dalam memberikan praktik perawatan yang komprehensif baik fisik dan psikososial pada pasien dengan gagal ginjal kronis yang 
menjalani hemodialisis terutama pada subjek gangguan citra tubuh yang akan mempengaruhi kesejahteraan spiritual pasien.

Copyright (C) 2019 Caring : Jurnal Keperawatan. All rights reserved

\section{${ }^{\star}$ Corresponding Author:}

Tendy Ar Riqi,

Prodi S1 IImu Keperawatan STIKes Guna Bangsa Yogyakarta,

JIn. Padaaran, Ngringin, Condongcatur, Depok, Sleman, D I Yogyakarta

Email: emailtendy@gmail.com

\section{PENDAHULUAN}

Gagal ginjal terjadi ketika ginjal tidak mampu mengeluarkan sisa metabolisme serta tidak mampu menjalankan fungsi regulasinya. Gagal ginjal terbagi menjadi 2 macam, gagal ginjal akut dan gagal ginjal kronik atau disebut juga end stage renal disease (ESRD). Gagal ginjal kronik (GGK) merupakan kondisi pasien yang mengalami penurunan fungsi hingga kerusakan ginjal yang berlanjut sehingga membutuhkan terapi pengganti ginjal secara terus menerus (Smeltzer, 2011). Berdasarkan data United States Renal Data System (USRDS) tahun 2014, lebih dari 30 juta warga Amerika Serikat menderita penyakit gagal ginjal kronik, angka ini meningkat sekitar $8 \%$ setiap tahunnya (USRDS, 2015). Indonesia sendiri termasuk ke dalam 10 besar negara di Asia dengan kasus penyakit gagal ginjal tertinggi. Prevalensi penderita GGK di Indonesia pada tahun 2007 yang terdata berjumlah 6.882 pasien. Sedangkan pada tahun 2014 meningkat menjadi 28.882 (Pernefri, 2014). Menurut data rekam medik RS PKU Muhammadiyah Gamping pasien yang mengalami gangguan ginjal yang menjalani hemodialisis rata - rata melakukan kunjungan pada periode November 2015 - 2016 sejumlah 1.100 kunjungan dari 145 pasien.

Pasien GGK tidak akan mengalami penyembuhan karena sifatnya yang ireversibel. Maka dari itu, GGK memerlukan terapi pengganti ginjal yang tetap, berupa dialisis atau transplantasi ginjal. Dialisis merupakan pengobatan pengganti pada pasien GGK yang dibedakan menjadi dua, yaitu dialisis peritoneal dan hemodialisis (Price \& Wilson, 2006). Hemodialisis adalah suatu bentuk tindakan pertolongan yang menggunakan alat yaitu dializer yang bertujuan untuk menyaring dan membuang sisa produk metabolisme toksik yang seharusnya dibuang oleh ginjal. GGK. Hemodialisis memerlukan waktu sekitar 3-5 jam dan dilakukan sekitar 3 kali seminggu (Rahman, 2014).

Tindakan hemodialisis dilakukan secara rutin dan dalam jangka waktu seumur hidup. Kondisi tersebut tentu saja akan mempengaruhi perubahan bio - psiko - sosio spiritual dalam kehidupannya. Perubahan biologis (fisik), seperti harus mengatur pola pola hidupnya yaitu pola makan, pola minum (intake cairan), pola aktivitas dan pola istirahat, semua ini harus seimbang. Perubahan psikologis, termasuk di dalamnya ialah kecemasan, ancaman akan kematian, perasaan bersalah karena terus bergantung pada orang lain, merasa tidak berguna, dan tidak berharga. Hal tersebut dapat mengakibatkan klien merasa tidak mampu dan tidak berdaya karena keterbatasan fisiknya, sehingga klien menjadi malu/ minder, tidak mau berteman dengan orang lain, tidak melakukan kegiatan sosial atau mengalami perubahan secara sosial. Perubahan spiritualnya, klien merasa tidak mampu melakukan kegiatan keagamaan (Lubis, 2006).

Masalah yang terjadi pada pasien yang menjalani hemodialisis dapat berdampak pada citra tubuh. Citra tubuh merupakan kumpulan dari seluruh keadaan ini, disadari maupun tidak disadari, yang seseorang miliki dalam tubuhnya (Berman, Snyder, \& Frandsen, 2016). Gangguan citra tubuh diakibatkan oleh perubahan yang terjadi terhadap fungsi maupun kondisi fisik seseorang (Potter \& Perry, 2009). Tanda dan gejala seseorang mengalami gangguan citra tubuh yakni menolak melihat dan menyentuh bagian tubuh yang telah berubah, tidak menerima perubahan tubuh yang telah terjadi 
atau akan terjadi, menolak penjelasan perubahan tubuh, persepsi negatif terhadap tubuh, preokupasi dengan bagian tubuh yang hilang, dan mengungkapkan keputusasaan dan ketakutan (Kusumawati \& Hartono, 2010).

Citra tubuh dipengaruhi oleh beberapa faktor, salah satunya adalah spiritualitas (Wilkinson, 2016). Salah satu variabel yang merupakan bentuk pengembangan dalam spiritualitas ialah kesejahteraan spiritual. Kesejahteraan spiritual menurut National Interfaith Coalition on Aging (NICA) merupakan sebuah afirmasi/ pernyataan hidup yang dimiliki seseorang dalam hubungannya dengan Tuhan, diri, komunitas dan lingkungan yang memelihara dan mempengaruhi keutuhan diri seseorang (Moberg, 2012).

Pasien GGK yang menjalani terapi hemodialisis menggunakan spiritualitas dan religiusitas sebagai koping utama dalam mencapai kesejahteraan spiritual (Cheawchanwattana, Chunlertrith, \& Saisunantararom, 2015). Dalam penelitian yang dilakukan Davidson dan Jhangri pada tahun 2010 terhadap 253 pasien GGK yang menjalani hemodialisis didapatkan bahwa sebesar 53\% pasien menyebutkan bahwa spiritual adalah kebutuhan yang penting dalam menemukan suatu harapan hidup. Menurut NANDA-I (2014), spiritualitas merupakan salah satu faktor yang mempengaruhi citra tubuh seseorang (Herdman \& Kamitsuru, 2014).

Berdasarkan studi pendahuluan yang dilakukan di RS PKU Muhammadiyah Gamping pada tanggal 2 Desember 2016, data yang didapatkan dari wawancara dengan delapan responden terkait citra tubuhnya, didapatkan data terkait aspek psikomotor, delapan diantaranya mengaku dirinya semenjak menjalani hemodialisis sudah tidak berdaya untuk bekerja lagi. Saat ditanya mengenai perasaannya terhadap kondisi fisiknya setelah menjalani hemodialisis, empat responden merasa malu untuk berinteraksi dengan orang lain dikarenakan perubahan warna kulit dan sering batuk batuk. Ketika ditanyakan terkait aspek kognitifnya, lima diantaranya mengaku kurang puas terhadap kondisi tubuhnya dan tiga lainnya merasa pasrah dan hanya di rumah menerima dengan keadaannya.

Tidak hanya mengenai citra tubuh, delapan responden juga diwawancarai mengenai keempat dimensi kesejahteraan spiritual, yang pertama mengenai hubungannya dengan diri sendiri, enam diantaranya mengaku setelah rutin menjalani hemodialisis, hidupnya menjadi tidak bisa menemukan kenyamanan diri dan menjadi kurang percaya diri akibat ketidakberdayaan dalam melakukan segala aktivitas. Saat ditanya terkait hubungannya dengan orang lain empat diantaranya mengaku bahwa dirinya malu untuk berinteraksi dengan kerabat dan tetangganya karena perubahan yang terjadi pada tubuhnya akibat efek samping hemodialisis. Tiga responden merasa menyerah dan tidak mempunyai tujuan hidup, dan kedelapan pasien mengaku mengalami kesulitan dalam melakukan kegiatan ibadah dan kadang hanya terlewatkan saja. Pernyataan survei awal tersebut sesuai dengan penelitian yang telah dilakukan oleh Farida (2010) tentang pengalaman pasien hemodialisis terhadap kualitas hidup dalam konteks asuhan keperawatan di RSUP Fatmawati Jakarta. Penelitian ini menjelaskan bahwa pasien yang menjalani hemodialisis akan mengalami perubahan baik dari segi kondisi fisik, psikologis, sosial dan ekonomi maupun spiritual, yang terkadang akan menimbulkan gangguan pada citra tubuh penderitanya.

Berbagai penelitian dan literatur turut menyatakan bahwa hemodialisis dapat menyebabkan berbagai masalah yang akan mempengaruhi citra tubuh dan berdampak pada kesejahteraan spiritual pasien tersebut. Berdasarkan penjelasan dan fenomena diatas, peneliti tertarik untuk melakukan penelitian mengenai hubungan citra tubuh dengan kesejahteraan spiritual pasien hemodialisis. Adapun tujuan dari dilakukannya penelitian ini adalah untuk mengetahui hubungan antara citra tubuh dengan kesejahteraan spiritual pasien hemodialisis di RS PKU Muhammadiyah Gamping. Manfaat dilakukannya penelitian adalah agar penelitian ini dapat menjadi bahan masukan bagi unit hemodialisis RS PKU Muhammadiyah Gamping dalam memberikan pelayanan praktik keperawatan yang menyeluruh baik fisik maupun psikososial pada 
pasien yang menjalani hemodialisis terutama tentang masalah gangguan citra tubuh yang akan mempengaruhi kesejahteraan spiritual pasien.

\section{BAHAN DAN METODOLOGI PENELITIAN}

Metode yang digunakan dalam penelitian ini yaitu deskriptif korelasi dengan pendekatan cross sectional. Sampel pada penelitian ini pasien gagal ginjal kronik yang menjalani hemodialisis yang berjumlah 60 orang. Pengambilan sampel menggunakan teknik purposive sampling. Kuesioner terdiri dari data demografi responden dan 2 instrumen dari masing - masing variabel. Instrumen yang digunakan adalah kuesioner BIS (body image scale) dan FACIT - Sp (Functional Assessment Chronic Illnes Therapy - Spiritual) yang telah dialihbahasakan dan diuji validitas dan reliabilitas. Data dianalisis secara univariat dan bivariat (chi square).

\section{HASIL DAN PEMBAHASAN}

Tabel 1. Distribusi frekuensi karakteristik responden berdasarkan usia, jenis kelamin, pendidikan, dan lama pasien menjalani hemodialisis di RS PKU Muhammadiyah Gamping pada bulan Mei 2017

\begin{tabular}{ccc}
\hline Karakteristik & Frekuensi (f) & Persentase (\%) \\
\hline Usia & 11 & \\
$26-35$ tahun & 23 & 18,3 \\
$36-45$ tahun & 18 & 38,3 \\
$46-55$ tahun & 8 & 30,0 \\
$55-65$ tahun & 36 & 13,4 \\
Jenis kelamin & 24 & 60,0 \\
Laki - laki & & 40,0 \\
Perempuan & 60 & \\
Agama & 0 & 100,0 \\
Islam & 0 & 0,0 \\
Katolik & 0 & 0,0 \\
Kristen & 0 & 0,0 \\
Hindu & & 0,0 \\
Budha & 2 & 3,3 \\
Pendidikan & 10 & 16,7 \\
SD & 30 & 50,0 \\
SMP & 18 & 30,0 \\
SMA & & \\
Perguruan Tinggi & 22 & 36,7 \\
Lama menjalani & 28 & 46,7 \\
hemodialisa & 10 & 16,6 \\
<2 tahun & & 100 \\
2- 4 tahun & 60 & \\
$>4$ tahun & & \\
Total & & \\
\hline
\end{tabular}

Tabel 1 memperlihatkan karakteristik responden subjek penelitian. Mayoritas responden berada pada rentang umur $36-45$ tahun yaitu sebanyak 23 orang $(38,3 \%)$, berjenis kelamin laki-laki sebanyak 36 orang $(60 \%)$, beragama islam sebanyak 60 orang $(100 \%)$, berjenjang pendidikan terakhir SMA sejumlah 30 orang $(50 \%)$, dan telah menjalani hemodialisis antara 2-4 tahun sebanyak 28 orang (46,7\%). 
Tabel 2. Distribusi responden berdasarkan citra tubuh dan kesejahteraan spiritual di RS PKU Muhammadiyah Gamping pada bulan Mei 2017

\begin{tabular}{ccc}
\hline Variabel & Frekuensi (f) & Persentase (\%) \\
\hline Citra Tubuh & & \\
Positif & 51 & 85,0 \\
Negatif & 9 & 15,0 \\
\hline Kesejahteraan spiritual & & \\
Baik & 5 & 8,3 \\
Cukup & 3 & 86,7 \\
Kurang & 60 & 5,0 \\
\hline Total & & 100 \\
\hline
\end{tabular}

Tabel 2 menunjukkan bahwa terdapat 9 orang (15\%) yang memilki citra tubuh negatif dan terdapat mayoritas responden dengan kesejahteraan spiritual dalam kategori cukup sejumlah 52 orang $(86,7 \%)$.

Berdasarkan pengolahan data dengan bantuan penghitungan statistik melalui komputer diperoleh hasil penghitungan yang dapat dilihat pada tabel 3 sebagai berikut:

Tabel 3. Hubungan Citra Tubuh dengan Kesejahteraan Spiritual Pasien yang Menjalani Hemodialisis diatas menggambarkan hubungan antara citra tubuh dengan kesejahteraan spitirual pasien hemodialisis di RS PKU Muhammadiyah Gamping.

\begin{tabular}{ccccccc}
\hline \multirow{2}{*}{ Variabel } & & \multicolumn{6}{c}{ Kesejahteraan spiritual } & Nilai & \\
\cline { 3 - 7 } & & Kurang & Cukup & Baik & $\begin{array}{c}\text { p- } \\
\text { value }\end{array}$ & Chi square \\
Citra tubuh & Positif & $1(1,7 \%)$ & $45(75,0 \%)$ & $5(8,3 \%)$ & 0,027 & 7,260 \\
& Negatif & $2(3,3 \%)$ & $7(11,7 \%)$ & $0(0,0 \%)$ & & \\
\hline
\end{tabular}

Tabel 3 dapat dilihat bahwa terdapat sejumlah 45 orang (75\%) dengan citra tubuh positif dan kesejahteraan spiritual dalam kategori cukup. Hasil perhitungan diperoleh nilai $x^{2}$ hitung sebesar 7,260 dan probabilitas sebesar $0,027 \quad(0,027<0,05)$, maka Ha diterima dan Ho ditolak. Hal ini menunjukkan bahwa terdapat hubungan yang signifikan antara variabel citra tubuh dengan kesejahteraan spiritual pasien hemodialisis di RS PKU Muhamadiyah Gamping. Koefisien kontingensi adalah sebesar 0,329.

Hasil penelitian menunjukkan bahwa mayoritas responden yang menjalani hemodialisis berusia dewasa akhir atau berkisar antara 36-45 tahun. Departemen kesehatan menerangkan bahwa umur adalah lama waktu hidup atau ada (sejak dilahirkan atau diadakan). Usia dikelompokkan menjadi masa balita (0-5 tahun), kanak - kanak (5-11 tahun), remaja awal (12-16 tahun), remaja akhir (17-25 tahun), dewasa awal (26-35 tahun), dewasa akhir (3645 tahun), lansia awal (46-55 tahun), lansia akhir (56-65 tahun), dan manula (65 keatas) (Depkes RI, 2009). Usia juga erat kaitannya dengan prognosis penyakit dan harapan hidup mereka yang berusia diatas 55 tahun kecenderungan untuk terjadi berbagai komplikasi yang memperberat fungsi ginjal sangat besar bila dibandingkan dengan yang berusia dibawah 40 tahun. Bertambahnya usia lebih berpengaruh terhadap penurunan kapasitas kemampuan fisik pasien, sedangkan pada aspek emosional dan fungsi sosial tidak banyak dipengaruhi oleh bertambahnya usia.Bahkan dengan bertambahnya usia, pasien akan semakin matang sehingga kemampuan menerima kondisi sakit dan adaptasi psikologis akan lebih baik (Berman et al., 2016).

Berdasarkan penelitian di suatu rumah sakit Brazil, usia rata-rata umur pasien gagal ginjal kronik yang menjalani hemodialisis adalah 51,9 tahun dengan rentang usia 
2876 tahun (Ana et al, 2013). Penelitian lainnya yang juga dilakukan di Brazil, usia ratarata pasien gagal ginjal kronik yang menjalani hemodialisis adalah 50,4 tahun dengan kelompok usia terbanyak 58-62 tahun (Cabral et al, 2005). Penelitian di rumah sakit daerah Jakarta menyatakan bahwa usia rata-rata pasien gagal ginjal kronik yang menjalani hemodialisis adalah 50,4 tahun (Junaidi, 2009).

Dari hasil penelitian ini bahwa pasien gagal ginjal kronik yang menjalani terapi hemodialisis di Rumah Sakit Umum PKU Muhammadiyah Gamping, responden berjenis kelamin laki-laki memiliki frekuensi lebih banyak bila dibandingkan dengan responden perempuan. Pasien laki-laki yang lebih banyak bila dibandingkan dengan pasien perempuan kemungkinan disebabkan oleh beberapa hal. Pembentukan batu renal lebih banyak diderita oleh lakilaki karena saluran kemih pada lakilaki lebih panjang sehingga pengendapan zat pembentuk batu lebih banyak daripada perempuan. Pembesaran prostat pada laki-laki dapat menyebabkan terjadinya obstruksi dan infeksi yang dapat berkembang menjadi gagal ginjal. Laki - laki juga lebih banyak mempunyai kebiasaan yang dapat mempengaruhi kesehatan seperti merokok, minum kopi, alkohol, dan minuman suplemen yang dapat memicu terjadinya penyakit sistemik yang dapat menyebabkan penurunan fungsi ginjal dan berdampak terhadap kualitas hidupnya (Smeltzer, 2011). Hasil yang serupa juga dinyatakan dalam sebuah penelitian di Rumah Sakit Prof. Dr. Margono Soekarjo Purwokerto bahwa lebih banyak laki-laki yang menjalani hemodialisis berjumlah $58,4 \%$ bila dibandingkan dengan pasien perempuan yang berjumlah 41,6\% (Cahyu, 2011).

Sebagian besar pasien hemodialisis di RS PKU Muhammadiyah Gamping berpendidikan SMA, pendidikan erat kaitannya dengan pengetahuan. Salah satu faktor yang mempengaruhi pengetahuan adalah pendidikan. Hal ini dikarenakan semakin tinggi pendidikan seseorang maka kemampuan serta pemahaman tentang gagal ginjal akan semakin tinggi. Pendidikan yang tinggi akan membuat seseorang akan cenderung untuk mendapatkan informasi lebih, baik dari orang lain maupun dari media masa. Semakin banyak informasi yang masuk semakin banyak pula pengetahuan yang didapat tentang kesehatan. Pengetahuan sangat erat kaitannya dengan pendidikan dimana diharapkan seseorang dengan pendidikan tinggi, maka orang tersebut akan semakin luas pula pengetahuanya. Pengetahuan tidak hanya diperoleh di pendidikan formal, akan tetapi dapat diperoleh pada pendidikan non formal, pengetahuan seseorang tentang sesuatu obyek juga mengandung dua aspek yaitu aspek positif dan negatif. Kedua aspek inilah yang akhirnya akan menumbuhkan sikap seseorang terhadap suatu obyek tersebut (Notoatmodjo, 2012). Hasil penelitian ini sesuai dengan teori yang mengatakan bahwa pendidikan merupakan dasar utama untuk keberhasilan pengobatan. Pendidikan mempengaruhi pengetahuan seseorang mengenai gagal ginjal kronik dan efek samping yang terjadi apabila melakukan terapi hemodialisis, seseorang yang tidak memiliki cukup pengetahuan yang disebabkan pendidikan yang rendah kemungkinan akan merasakan tekanan dan frustasi pada saat menjalani terapi hemodialisis karena terjadi perubahan tubuh yang drastis (Gultom, 2012).

Penderita gagal ginjal kronik yang memiliki pendidikan lebih tinggi akan empunyai pengetahuan yang lebih luas juga memungkinkan pasien itu dapat mengontrol dirinya dalam mengatasi masalah yang dihadapi, mempunyai rasa percaya diri yang tinggi, berpengalaman, dan mempunyai perkiraan yang tepat bagaimana mengatasi kejadian, mudah mengerti tentang apa yang dianjurkan oleh petugas kesehatan, serta dapat mengurangi kecemasan sehingga dapat membantu individu tersebut dalam membuat keputusan (Kusumawardhani, 2010).

Lama menjalani terapi hemodialisis merupakan rentang waktu pasien menjalani hemodialisis. Hasil penelitian menunjukkan bahwa mayoritas lama pasien gagal ginjal kronik yang menjalani terapi hemodialisis di Rumah Sakit PKU Muhammadiyah Gamping adalah kisaran 2-4 tahun, yang terlama adalah 8 tahun dan yang terbaru adalah 3 bulan. Rentang waktu lama menjalani hemodialisis pada pasien gagal ginjal kronik sangat 
berpengaruh terhadap keadaan dan kondisi pasien baik fisik maupun psikisnya, perasaan takut adalah ungkapan emosi dari pasien yang paling sering diungkapkan. Pasien sering merasa takut akan masa depan yang akan dihadapi dan perasaan marah yang berhubungan dengan pertanyaan mengapa hal tersebut terjadi pada dirinya. Ketakutan dan keputusasaan juga kerap datang karena pasien harus bergantung dengan alat hemodialisis seumur hidupnya. (Cahyu, 2011). Hasil penelitian ini tidak berbeda jauh dengan penelitian yang mengemukakan bahwa lama pasien menjalani hemodialisis adalah yang terlama 14 tahun dan yang terbaru adalah 4 bulan (Suryarinilsih, 2010).

Hasil distribusi frekuensi menunjukan bahwa pasien yang menjalani terapi hemodialisis di RS PKU Muhammadiyah Gamping masih terdapat sejumlah 15\% memiliki citra tubuh yang negatif. Hasil analisis deskriptif menyebutkan bahwa mayoritas responden yang mempunyai citra tubuh negatif terganggu pada aspek kognitifnya. Pada dasarnya setiap individu adalah unik, tidak semua orang mengalami gangguan citra tubuh, namun dalam penelitian ini jumlah pasien hemodialisis yang mengalami gangguan citra tubuh cukup banyak dan hanya sejumlah 9 orang. Teori yang mendukung bahwa adanya perubahan fungsi struktur tubuh dan adanya tindakan hemodialisis akan menyebabkan pasien gagal ginjal kronik mengalami gangguan citra tubuh. Hal ini disebabkan karena koping pasien yang maladaptive (Muttaqin \& Sari, 2011). Kajian citra tubuh lebih banyak menyoroti seseorang yang memiliki berat badan berlebih (overweight). Namun ternyata bukan hanya overweight yang mengalami gangguan citra tubuh tetapi juga kehilangan berat badan (weight loss). Seseorang yang mengalami penurunan berat badan juga berpotensi untuk berdampak pada citra tubuhnya (Cash, 2006). Sama halnya dengan penderita penyakit kronis seperti penderita penyakit ginjal yang menjalani hemodialisis. Mereka mengalami penurunan berat badan yang menjadikan dirinya kurus sedangkan perut mereka membesar. Hal tersebut membuat mereka menilai dan mempersepsikan penampilan mereka secara negatif. Bukan hanya karena mereka mengalami penurunan berat badan yang awalnya menurut mereka ideal, namun juga mereka mengalami perubahan tampilan fisik pada beberapa bagian tubuh seperti misalnya perut membesar, kaki membengkak, rambut rontok, kulit kering dan menghitam padahal jarang beraktivitas di luar rumah (Checherita, 2010).

Berdasarkan hasil pengolahan data, bahwa penyakit yang dialami dan prosedur terapi hemodialisis yang dijalani oleh responden menimbulkan gangguan pada aspek kognitifnya yang berkaitan dengan adanya perubahan pada kondisi fisik maupun fungsi tubuhnya. Perubahan kondisi fisik menyebabkan aktivitas responden menjadi terhambat dan tidak dapat beraktivitas seperti semula karena kondisi fisiknya yang berubah, seperti mudah lelah dan bagian - bagian tubuh berubah seperti kaki membengkak, perut membuncit, kulit menghitam dan banyak bekas suntikan jarum saat hemodialysis (Safarudin, 2012). Persepsi yang dimiliki responden mengenai tubuhnya yaitu dengan kata lain citra tubuh responden pun menjadi kurang baik, hal ini disebabkan banyaknya perubahan yang terjadi pada penampilan fisiknya sedangkan mereka menyatakan bahwa mereka ingin sama seperti orang lain yang sehat dan berpenampilan menarik. Mereka tak ingin dikomentari negatif oleh teman dan keluarganya. Mereka berpikir bahwa mereka dihukum dan merasa tidak berharga (Safarudin, 2012). Hasil penelitian ini sejalan dengan penelitian yang dilakukan oleh Oxtavia (2013) yang menyatakan bahwa terdapat pasien gagal ginjal kronik yang menjalani hemodialisis mengalami gangguan citra tubuh. Hal tersebut dapat terjadi akibat rasa nyeri, mobilisasi aktivitas yang terbatas akibat pasien sering merasa cepat lelah, pekerjaan yang tidak maksimal, hubungan sosial pasien dengan masyarakat sekitarnya yang kurang baik maupun kurangnya dukungan dari keluarga dan rasa aman yang tidak terpenuhi serta keuangan yang terbatas. Peneliti menyimpulkan bahwa pasien tersebut mengalami gangguan pada domain fisik, hubungan sosial dan lingkungan, namun pasien tersebut tidak 
mengalami gangguan pada domain psikologis, dikarenakan pasien selalu berfikir positif dan memiliki spiritual yang baik.

Hasil distribusi frekuensi menunjukkan bahwa paling banyak responden memberikan penilaian variabel kesejahteraan spiritual dalam kategori cukup. Hasil penelitian menunjukkan bahwa mayoritas pasien hemodialisis di RS PKU Muhammadiyah Gamping memiliki tingkat kesejahteraan spiritual cukup. Peneliti berasumsi bahwa ketika pasien gagal ginjal kronik telah mengetahui bahwa hemodialisis bukanlah terapi yang dapat menyembuhkan kondisinya, pasien mulai melalui tahapan penolakan hingga mencapai kondisi menerima akan keadaan yang dialaminya. Pada tahapan ini, pasien mulai dapat meningkatkan kesejahteraan dirinya. Sebuah penelitian menyebutkan bahwa spiritualitas merupakan komponen penting dari kesejahteraan individu untuk meningkatkan kemampuan seorang pasien dalam meningkatkan koping adaptif terhadap penyakit (Ebrahimi, Ashrafi, Eslampanah, \& Noruzpur, 2014). Hal tersebut sesuai dengan penelitian yang mengatakan bahwa pasien - pasien dengan kondisi kronis dapat ditemukan adanya peningkatan kesejahteraan spiritual (Bredle, Salsman, Debb, Arnold, \& Cella, 2011). Semakin kuat komitmen spiritual klien maka akan lebih mampu mengatasi masalah dan penderitaan (Kao, 2009). Sebuah penelitian yang dilakukan oleh Kutner (2013) terhadap pasien gagal ginjal kronik didapatkan sebesar $85,7 \%$ pasien menyebutkan bahwa spiritualitas adalah kebutuhan yang penting. Pasien gagal ginjal yang menjalani hemodialisis akan meningkatkan kesejahteraan spiritual setelah mendapatkan kembali makna dalam hidupnya (Candy, 2009).

Hasil tabulasi silang menunjukan bahwa frekuensi citra tubuh dengan kesejahteraan spiritual terbanyak adalah citra tubuh dalam kategori positif dan kesejahteraan spiritual dalam kategori cukup sebanyak $75 \%$. Hasil perhitungan Chi square di peroleh nilai $x^{2}$ hitungan sebesar 7,260 dan $p$-value sebesar $0.027(0.027<$ 0,05), maka Ha diterima (hipotesa diterima) dan Ho ditolak. Hal ini menunjukan bahwa terdapat hubungan yang signifikan antara variabel citra tubuh dengan kesejahteraan spiritual pasien yang menjalani terapi hemodialisis di RS PKU Muhammadiyah Gamping. Dilihat dari hasil nilai korelasi diatas menunjukan bahwa hubungan antara variabel citra tubuh dengan kesejahteraan spiritual semakin negatif citra tubuh pasien semakin buruk kesejahteraan spiritual pasien begitu juga sebaliknya.

Hasil dari perhitungan koefisien kontingensi adalah sebesar 0,329. Peneliti mendapati keeratan antara citra tubuh dengan kesejahteraan spiritual sesuai nilai bahwa cenderung berada pada kategori lemah, karena berada pada interval 0,2-0,399. Hubungan yang signifikan antara kesejahteraan spiritual dengan citra tubuh pasien hemodialisis menunjukkan adanya pengaruh yang besar antara keduanya. Dampak pada klien yang mengalami hemodialisis cenderung akan mengalami perubahan fisik atau perilakunya antara lain, gangguan citra tubuh yang meliputi, perubahan ukuran tubuh, perubahan bentuk tubuh, keterbatasan gerak. Berbagai masalah dan komplikasi dapat terjadi pada pasien yang menjalani hemodialisis (Oxtavia, 2013). Gangguan citra tubuh merupakan salah satu masalah yang akan di alami pasien GGK yang menjalani hemodialisis akibat adanya perubahan fungsi struktur tubuh pasien (Muttaqin \& Sari, 2011). Ketidakpuasan dan malu terhadap perubahan pada diri seseorang juga berhubungan dengan meningkatnya tingkat kecemasan dan depresi, dan juga menurunnya kualitas hidup (Jafari \& Esmaeli, 2015). Penelitian di Thailand menyebutkan bahwa kesejahteraan spiritual dipandang sebagai komponen esensial dari kualitas hidup kaitannya dengan kesehatan (healthrelated Quality of Life) dalam modernisasi konsep model kesehatan bio-psiko-sosio-spiritual (Cheawchanwattana et al., 2015). Secara tidak langsung dapat disimpulkan bahwa pasien yang mengalami gangguan citra tubuh memiliki peluang yang sangat kecil untuk memiliki kesejahteraan spiritual yang baik. Hal ini sesuai dengan teori Riyadi dan Purwanto (2009) yang menyatakan bahwa setiap perubahan tubuh akan mempengaruhi kehidupan individu. 


\section{KESIMPULAN}

Berdasarkan hasil uji analisa bivariat menggunakan uji chi square didapatkan $p$ value $0,027<\alpha 0,05$ yang artinya ada hubungan antara citra tubuh dengan kesejahteraan spiritual pasien yang menjalani hemodialisis di ruang Hemodialisis RS PKU Muhammadiyah Gamping. Nilai koefisien kontingensi adalah 0,329, hal ini menunjukkan keeratan antara variabel citra tubuh dengan kesejahteraan spiritual termasuk dalam kategori lemah karena berada di dalam interval 0,2-0,399. Penelitian ini dapat menjadi masukan bagi unit hemodialisis dalam memberikan pelayanan praktik keperawatan yang menyeluruh baik fisik maupun psikososial pada pasien dengan GGK yang menjalani hemodialisis terutama tentang masalah gangguan citra tubuh yang akan mempengaruhi kesejahteraan spiritual pasien.

\section{DAFTAR PUSTAKA}

Berman, A., Snyder, S. J., \& Frandsen, G. (2016). Kozier \& Erb's Fundamental of Nursing: Concepts, Process, and Practice (10th ed.). USA: Pearson Education.

Bredle, J. M., Salsman, J. M., Debb, S. M., Arnold, B. J., \& Cella, D. (2011). Spiritual Well-Being as a Component of Health-Related Quality of Life: The Functional Assessment of Chronic Illness Therapy-Spiritual Well-Being Scale (FACIT-Sp). Religions, 2(1), 77-94. http://doi.org/10.3390/rel2010077

Cabral, P. C., Diniz, A. D., \& De Arruda, I. K. G. (2005). Vitamin A and Zinc Status in Patients on Maintenance Haemodialysis. Nephrology, 10: 459 - 463. doi: 10.1111/j. 1440-1797.2005. Diakses pada tanggal 22 Mei 2017 dari http://www.ncbi.nlm.nih.gov

Cahyu, S. (2011). Hubungan Antara Adekuasi Hemodialisis dengan Kualitas Hidup Pasien Hemodialisis RS Prof. Dr. Margono Soekarjo Purwokerto. Jurnal FIK UI. Diakses dari http://fik.ui.ac.id pada tanggal 22 Mei 2017

Caldeira, S., Carvalho, E. C., \& Vieira, M. (2009). Spiritual Distress - Proposing a New Definition and Defining Characteristics. The Official Journal of NANDA International, 2002, 1-8.

Candy, B. (2009). Spiritual and Religious Intervention For Adults in Terminal Phase of Disease (Protocol). The Cochrene Collaboration. Diakses pada 22 Mei 2017 dari http://www.thecochranelibrary.com

Cash, T. F \& Pruzinsky. T. (2006). Body Image: A Handbook of Theory, Research, and Clinical Practice. New York: Guilford Press.

Cheawchanwattana, A., Chunlertrith, D., \& Saisunantararom, W. (2015). Does the Spiritual WellBeing of Chronic Hemodialysis Patients Differ from that of Predialysis Chronic Kidney Disease Patients?, 14-23. http://doi.org/10.3390/rel6010014

Checherita, I. A. (2010). Chronic Complications in Hemodialysis : Correlations with Primary Renal Disease. Romanian Journal of Morphology and Embryology, 51(1), 21-26.

Ebrahimi, H. (2014). The Relationship between Hemodialysis Adequacy and Quality of Life and Spiritual Wellbeing in Hemodialysis

Patients. Journal of Clinical Nursing and Midwifery. 3 (3): 4451. Diakses pada tanggal 22 Mei 2017 dari http://jicnm.skums.ac.ir

Farida, A. (2010). Pengalaman Pasien Hemodialisis Terhadap Kualitas Hidup Dalam Konteks Asuhan Keperawatan Di Rsup Fatmawati Jakarta. Diakses pada tanggal 14 Mei 2017 dari http://portagaruda.id

Gultom, T. Y. (2012). Tingkat Pengetahuan Pasien Diabetes Mellitus tentang Manajemen Diabetes Mellitus. Diakses pada $22 \quad$ Mei 2017 dari

http://lontar.ui.ac.id/info

Herdman, T. H., \& Kamitsuru, S. (2014). Nursing 20152017 (10th ed.). Oxford: Wiley Blackwell.

Diagnoses: Definition \& Classification

Junaidi, M. A. (2009). Status Indeks Massa Tubuh Pasien Penyakit Ginjal Kronik yang Menjalani Hemodialisis di RS Cipto Mangunkusumo dan Korelasinya dengan Lama Menjalani 
Hemodialisis. Jurnal SkripsiThesis FK UI. Diakses pada 22 Mei 2017 dari http://fkui.ac.id

Kao, T.-W. (2009). Correlations Between Spiritual Beliefs and Health-Related Quality of Life of Chronic Hemodialysis Patients in Taiwan. Artificial Organs. 33: 576-579. doi:10.111/j.1525-1594.2009.00739

Kemenkes RI (2009). Petunjuk Teknis Pengendalian Penyakit Ginjal Kronik. Bakti Husada. Jakarta.

Kusumawardhani. (2010). Hubungan Karakteristik Individu dengan Kualitas Hidup Dimensi Fisik Pasien Gagal Ginjal Kronik di Rs Dr. Kariadi Semarang. Diakses pada tanggal $22 \mathrm{Mei}$ 2017 dari http://digilib.unimus.ac.id

Kusumawati, F., \& Hartono, Y. (2010). Buku Ajar Keperawatan Jiwa. Jakarta: Salemba Medika.

Kutner, J. S. (2013). Behaviour of Hemodialysis Patients. Journal of Social Science \& Medicine. Diakses pada 22 Mei 2017 dari http://www.ncbi.nlm.nih.gov

Lubis, A. J. (2006). Dukungan Sosial pada Pasien Gagal Ginjal Terminal yang Melakukan Terapi Hemodialisa. Retrieved from repository.usu.ac.id/ bitstream/123 456789/1920/1/06010311.pdf

Moberg, D. O. (2012). Aging and Spirituaity: Spiritual Dimensions of Aging Theory, Research, Practice, and Policy. New York: The Haworth Press.

Muttaqin, A., \& Sari, K..(2011). Asuhan Keperawatan Gangguan System Perkemihan. Jakarta: Salemba Medika

Notoatmodjo, S. (2012). Promosi Kesehatan dan IImu Perilaku Edisi Revisi. Jakarta: Rineka Cipta.

Notoatmodjo, S. (2012). Metodologi Penelitian Kesehatan. Jakarta: Rineka Cipta.

PERNEFRI. (2014). 7 th Report Of Indonesian Renal Registry 2014, 7th. Retrieved from http://www.indonesianrenalregistry.org/data/INDONESIAN RENAL REGISTRY 2014.pdf

Potter, P. A., \& Perry, A. G. (2009). Fundamental Keperawatan. Jakarta: Salemba Medika.

Price, S. A., \& Wilson, L. M. (2006). Patofisiologi: Konsep Klinis Proses - Proses Penyakit Ed. 6. Jakarta: EGC.

Rahman. (2014). Hubungan Tindakan Hemodialisis dengan Tingkat Kecemasan Pasien di Ruangan Hemodialisa RSUD Labuang Baji Sulawesi Selatan. Jurnal IImiah Kesehatan Diagnosis Nomor 5, 4. Diakses pada tanggal 23 November 2016 dari http://download.portalgaruda.org

Riyadi, S. \& Purwanto, T. (2009). Asuhan

Keperawatan Jiwa Yogyakarta: Graha IImu.

Safarudin, S. (2012). Hubungan Pola Terapi, Nilai Ureum-Kreatinin Plasma dan Hemoglobin dengan Kualitas Hidup Pasien Hemodialisis di RSUD Dr. Soedarso Pontianak. Thesis. Fakultas IImu Keperawatan Program Studi IImu Keperawatan Universitas Indonesia. Depok. Diakses pada tanggal 22 Mei 2017 dari http://fik.ui.ac.id

Smeltzer, S. C. (2011). Keperawatan Medikal Bedah Brunner \& Suddarth Ed. 12. Jakarta: EGC.

Suryarinilsih. (2010). Hubungan penambahan Berat Badan Antara Dua Waktu Dialisis dengan Kualitas Hidup Pasien Hemodialisis di Rumah Sakit Dr. M. Djamil Padang. Tesis tidak dipublikasi. Diakses 22 Mei 2017 dari http://flib.ui.ac.id

USRDS. (2015). 2015 USRDS Annual Data Report Volume 1: CKD in the United States, 1. Retrieved from https://www.usrds.org/2015/view/ default.aspx

Wilkinson, J. M. (2016). Diagnosis Keperawatan: Diagnosis NANDA - I, Intervensi NIC, Hasil NOC (10th ed.). Jakarta: EGC 